\title{
Exploring the recontextualisation of biology in the CAPS for Life Sciences
}

\section{Kathryn Johnson, Edith Dempster and Wayne Hugo}

\begin{abstract}
This study is concerned with the recontextualisation of biology in the most recent version of the South African Life Sciences curriculum, the CAPS (Curriculum and Assessment Policy Statements). The following aspects of the curriculum were assessed: the balance of canonical and humanistic material, the inclusion and weighting of the core concepts of biology, and the overall curriculum coherence. The results were compared with those for earlier versions of the curriculum, and the implications for South African students are considered. The study reveals that, according to these criteria, the content material of the CAPS faithfully reflects the hierarchical nature of its parent discipline biology.
\end{abstract}

\section{Introduction}

Since 1994, researchers, policy makers and practitioners have been grappling with how best to transform the education system in South Africa in order to realise the goal of social justice. Outcomes-based education, exemplified by Curriculum 2005, was initially touted as the means to this end and was a deliberate move away from the positivist nature of apartheid curricula. The disastrous consequences of this approach in terms of learner performance led to a series of curricular reviews, resulting in several versions of the National Curriculum Statement, the most recent being the Curriculum and Assessment Policy Statements (CAPS). The subject of this study is the CAPS for Life Sciences.

As someone whose life's work was driven by a deep concern for social justice, Basil Bernstein developed a sociology which has informed educational research in many contexts worldwide (e.g. Moore, Arnot, Beck and Daniels, 2006; Neves and Morais, 2001), as well as in post-apartheid South Africa (e.g. Bertram, 2008, 2009, 2012; Green and Naidoo, 2006; Hoadley, 2005; Johnson, 2009; Nsubuga, 2008). Bernstein's concepts of the 
recontextualisation of knowledge in the pedagogic device, knowledge classification and hierarchical knowledge structures provide the framework for this study, while Schmidt, Wang and McKnight's (2005) concept of curriculum coherence suggested a method for applying some these concepts to the curriculum. In the context of their application to the SA curriculum, these concepts have been elaborated on in some detail elsewhere (Johnson, Dempster and Hugo, 2011) and will be described only briefly here.

\section{Conceptual framework}

The recontextualisation of knowledge in the pedagogic device relates to the movement of knowledge from the field of production in tertiary academic institutions to the field of reproduction in schools, via the official recontextualising field of the curriculum (Bernstein, 1990). Knowledge is transformed as it moves through these fields of practice and is subject to the influence of the ideologies of agents of and stakeholders in curriculum construction; as a result, a school subject is different from its parent discipline. If the differences are too great, the ability of schools to reproduce specialised knowledge will be undermined, and learners - particularly those from disadvantaged backgrounds - will not be inducted successfully into the formal knowledge of the discipline (Muller, 2007).

Knowledge classification refers to the strength of the boundary between such formal disciplinary knowledge and everyday knowledge (Bernstein, 1996). In strongly classified knowledge systems the differences between formal and everyday knowledge are made explicit, and knowledge progresses from concrete examples to more abstract general principles or core concepts. According to Bernstein, strongly classified knowledge is more highly valued by society and thus empowers those learners who are inducted into its realms (Hasan, 2004).

This is particularly regarded as true for what Bernstein referred to as hierarchical knowledge structures, exemplified by the natural sciences including biology (Bernstein, 1996, 1999). Hierarchical knowledge structures are shaped by an internal logic (Christie, 2007) towards increasingly general theories or propositions which serve to integrate the knowledge of the discipline. Within biology, for example, the theory of evolution is widely 
regarded as the principle which integrates and makes sense of all other aspects of the discipline (e.g. Dobzhansky, 1973; Gould, 2002; Mayr, 2001)

Curriculum coherence was a concept utilised by Schmidt, Wang and McKnight (2005) to assess science content standards in the United States. The authors argued that in order to facilitate students' understanding of the subject matter of a hierarchical knowledge structure such as science, the curriculum must be coherent. By this they mean that foundational knowledge should be laid down before new topics are introduced, that the knowledge content must progress from particulars to deeper structures or from more concrete to more abstract knowledge, not simply be repeated from grade to grade, and that sensible connections should be made between topics both within and between grades. These principles can serve as criteria for assessing how faithfully hierarchical knowledge structures are recontextualised in a curriculum.

\section{Science curriculum revision}

Arguably one of the most revised curricular areas (Donnelly, 2006), science as a school subject (incorporating biology/life sciences) has tended to shift in emphasis over time and place between its more 'pure' and 'applied' forms, variously expressed as a pendulum swing between a 'science of life' versus a 'science for living' (Rosenthal and Bybee, 1987), 'science for future scientists' versus 'science for all' (Bennett, 2003) or a 'traditional/canonical' versus 'humanistic' approach (Aikenhead, 2006; Johnson, 2009). The traditional/canonical approach could be seen to equate to a strongly classified knowledge system sensu Bernstein (1996), while the humanistic approach would equate to a weakly classified knowledge system.

Shifts between the two emphases have typically reflected both the dominant educational ideology of the day (Rosenthal and Bybee, 1987), as well as the priorities of the agents of and stakeholders in curriculum construction (e.g. Barberá, Zanón and Pérez-Plá, 1999). Consensus has not been reached as to which emphasis better serves the needs of the learner and the cause of social justice, with Aikenhead (2006) for example arguing in favour of a more humanistic approach, and Donnelly (2006) arguing for a more traditional approach. 


\section{The Biology/Life Sciences curriculum in post-apartheid South Africa}

The biology curriculum in post-apartheid South Africa (i.e. for Grades 10-12, known as Life Sciences since 2006) has been subjected to a series of revisions (Dempster and Hugo, 2006; Doidge, Dempster, Crowe and Naidoo, 2008; Johnson et al., 2011). The Interim Core Syllabus of 1996 (KwaZulu-Natal Department of Education and Culture, n.d.) was replaced by the National Curriculum Statement (now known as the NCS 1; DoE, 2003) in 2006, and the NCS content specifications (for Life Sciences only) were reworked and promulgated as a 'new curriculum framework' (now known as the NCS 2) in 2007 (DoE, 2007). Johnson (2009; see also Johnson et al., 2011) performed a comparative analysis of the content specifications of these three versions through the lenses of Bernstein's concepts of hierarchical knowledge structures and the recontextualisation of knowledge in the pedagogic device, the balance of canonical versus humanistic biology, and the degree of coherence within the subject matter. The analysis was used to try to assess whether each successive revision represented an improvement on the previous version in terms of how faithfully the curriculum reflected its parent knowledge structure. The conclusion was reached that of the three versions, the NCS 2 had achieved this most successfully.

The NCS 2 was short-lived; however. In July 2009, the new Minister of Basic Education appointed a panel of experts to investigate the many complaints regarding shortcomings in the implementation of the NCS (DoE, 2009; Umalusi, 2014). One of the main areas of concern was the proliferation of curriculum policy and guideline documents. The result of this process was the development of the Curriculum and Assessment Policy Statements (the CAPS; DBE, 2011), which were intended to replace the multiplicity of curriculum documents with a single document per subject to guide teaching and assessment. The CAPS were implemented in Grade 10 in 2012, and were examined in the National Senior Certificate for the first time in 2014.

The CAPS for Life Sciences has already been subjected to scrutiny. Mnguni (2013) investigated the Grade 11 Life Sciences curriculum according to Schiro's (2008) four categories of curriculum ideology. Umalusi (the Council for Quality Assurance in General and Further Education and Training) undertook an in-depth study of the entire curriculum in order to establish its strengths, weaknesses and overall quality, and to make recommendations for 
its improvement to the Department of Basic Education and Training (Umalusi, 2014). The specific intention of the present study is to examine the relationship between the content specifications in the CAPS for Life Sciences and the parent knowledge structure of biology, according to the criteria established in Johnson's (2009) study, namely the balance of canonical versus humanistic biology, the inclusion and weighting of biology's core concepts, and the coherence of the subject matter. These results are placed in context by comparing them with those found for the three previous versions, namely the ICS, NCS 1 and NCS 2, in order to assess whether the CAPS represents a further improvement on the NCS 2 in terms of how biology as a hierarchical knowledge structure has been recontextualised in this latest version of the Life Sciences curriculum.

\section{Methods}

The material analysed was the content specifications of all three grades in the Curriculum and Assessment Policy Statement Grades 10-12: Life Sciences (hereafter known as the CAPS) (DBE, 2011; pp.10-65). In the curriculum these are listed grade by grade, using four 'knowledge strands' (Life at the molecular, cellular and tissue level, Life processes in plants and animals, Environmental studies, and Diversity, change and continuity) as organising devices. Within each knowledge strand, the content appears under the column headings Time, Topic, Content, Investigations and Resources. For the purposes of this study, only the text in the Topic, Content and Investigations columns was analysed. The methods used to analyse the CAPS were the same as those used in the previous study in order for valid comparisons to be made between the curricula (Johnson et al., 2011) and will be described below.

The text in the Content and Investigations columns was divided into 'statements' - one or more sentences, phrases or words which deal with a unit of information - and imported into separate rows in an Excel spreadsheet. The statements were then assigned to two sets of predetermined categories using a numerical code. The initial analysis coded the statements as being either 'canonical' (pertaining to canonical biological knowledge, or the development of skills which could be regarded as being specifically related to science) or 'humanistic' (pertaining to the development of more generic skills, or to applications, attitudes and values, and science as a human enterprise).

Appendix 1 elaborates on criteria used to assign statements to either canonical 
or humanistic biology, and provides examples of how various statements in the curricula were coded.

A second analysis coded the canonical statements according to seven broad themes in biology, namely Life at the molecular and cellular level, Inheritance, Evolution, Diversity, Plant structure and functioning, Animal structure and functioning and Ecology. These themes were previously established as basic categories which represent core concepts in biology in the field of knowledge production (see Johnson, 2009 or Johnson et al, 2011). Appendix 2 lists topics which may be incorporated within each theme. The weighting of each theme was determined by calculating the number of statements related to each theme as a percentage of the total number of canonical biology codings. In this analysis, only the statements regarded as canonical knowledge were included, and not those relating to the development of scientific skills.

In order to assess the coherence of the subject matter, the text was then mapped grade by grade (after the draft concept maps of Project 2061's Atlas of Science Literacy, 2006), with the four Knowledge Areas forming columns on the maps. This serves to provide a clear visual representation of conceptual progression, the extent to which topics are connected, and whether or not there is repetition of material from grade to grade. Topics (i.e. those listed in the Topic column in the curriculum) were placed into individual boxes, which were joined by solid lines if connections between them are explicitly stated in the curriculum (for example, 'link to tissues', p 25). If, according to our judgment, the topics are connected but this connection is not explicitly stated, the boxes were joined by broken lines.

\section{Results}

In the case of the first two analyses, the results obtained for the CAPS are given alongside those previously obtained for the ICS, NCS 1 and NCS 2 (Johnson et al., 2011) in order to facilitate comparisons between the curricula. In the case of the conceptual progression map, only that for the CAPS is included here. The maps for the other three curricula can be found in Johnson et al. (2011). 


\section{Balance of canonical and humanistic biology}

Four hundred and twenty-two statements were identified in the CAPS. Of these, $296(70.1 \%)$ were coded as canonical and $126(29.9 \%)$ as humanistic.

If this result is compared with those previously obtained for the ICS, NCS 1 and NCS 2 (Johnson, 2009), the following trend is revealed (see Figure 1):

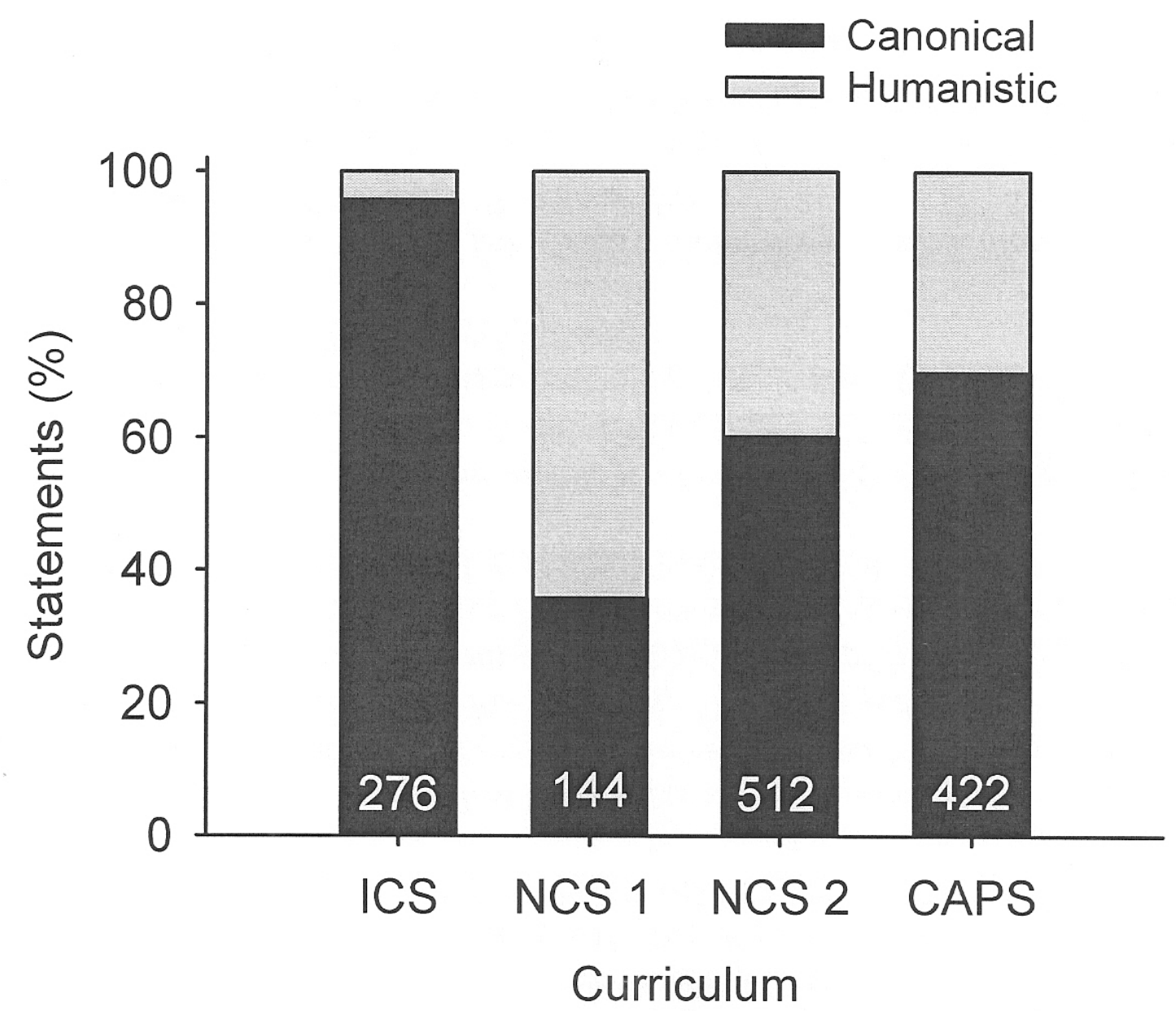

Figure 1: Relative percentages of canonical and humanistic biology statements in four consecutive versions of the South African Life Sciences curriculum. The number at the base of each bar represents the number of statements coded in each curriculum. (Results for the ICS, NCS 1 and NCS 2 from Johnson et al., 2011).

Weighting of core themes in biology

Table 1 below shows the weighting of the seven core themes in biology within the text identified as 'canonical'. In this analysis, only the statements 
regarded as canonical knowledge were included and not those relating to the development of scientific skills. This explains why the number of statements coded (245) in the case of the CAPS is less than that for all canonical statements (296).

Table 1: Weighting (\%) of canonical biology themes in four consecutive versions of the South African Life Sciences curriculum $(n=$ number of canonical statements coded)

\begin{tabular}{|l|c|c|c|c|}
\hline \multicolumn{1}{|c|}{ Theme } & $\begin{array}{c}\text { ICS } \\
(\mathbf{n = ~ 2 6 5 )}\end{array}$ & $\begin{array}{c}\text { NCS 1 } \\
(\mathbf{n}=\mathbf{5 2})\end{array}$ & $\begin{array}{c}\text { NCS 2 } \\
\mathbf{( n = 3 1 0}\end{array}$ & $\begin{array}{c}\text { CAPS } \\
\text { (n= 245) }\end{array}$ \\
\hline $\begin{array}{l}\text { Life at the molecular and } \\
\text { cellular level }\end{array}$ & 13 & 13.3 & 16.2 & 23.7 \\
Inheritance & 7.6 & 6.7 & 7.2 & 8.6 \\
Evolution & 0 & 20 & 9.6 & 13.5 \\
Diversity & 29.8 & 4.4 & 13.4 & 10.6 \\
Plant structure and functioning & 5.9 & 6.7 & 10.3 & 6.9 \\
$\begin{array}{l}\text { Animal structure and } \\
\text { functioning }\end{array}$ & 34.9 & 20 & 33.3 & 25.3 \\
Ecology & 8.8 & 28.9 & 10 & 11.4 \\
\hline
\end{tabular}

\section{Curriculum coherence}

Figure 2 shows the result of the mapping of the content topics in the CAPS. Note that only the text under the column heading Topic in the CAPS was included on the map due to space constraints. Solid lines connecting the topics boxes mean that connections are explicitly referred to in the curriculum: the directive "link to. .." (for example "link to nutrition and Grade 9", p.23) is given over 40 times in the content specifications. Broken lines connecting topic boxes indicate that, even though no specific directives have been given, the topics are connected according to our judgment. For example, we have connected DNA: the code of life to the topic Meiosis which in turn we have connected to Genetics and Inheritance, as the former two topics provide the foundational knowledge required for the latter two. 


\section{Discussion}

This study has examined the content specifications of the CAPS for Life Sciences according to three criteria - the balance of canonical versus humanistic biology, the inclusion and weighting of seven core themes in biology, and the coherence of the curriculum. These criteria were employed as tools for assessing the relationship between biology as the parent knowledge structure and the knowledge in the official recontextualising field, represented by the CAPS. The results were compared with those found for the three previous versions of the Life Sciences curriculum implemented in South Africa since 1994 (Johnson et al., 2011).

The balance of canonical versus humanistic biology (Figure 1) provides an indication of the strength of the boundary between formal and everyday knowledge in the curriculum. The ICS, based as it was on the 'Christian National Education'-inspired, 'white' South African biology curriculum, showed extremely strong knowledge classification in containing almost no humanistic content (4\%). Curriculum 2005, governed by the philosophy of outcomes-based education (OBE), deliberately collapsed the boundaries between formal and everyday knowledge on the premise that this would best serve the social justice imperative; however, it was shown that this had the opposite effect in increasing rather decreasing inequalities in terms of educational performance between advantaged and disadvantaged students (Chisholm, 2000; Muller, 2000). Nevertheless, the NCS 1, implemented in 2006, was still governed by the principles of OBE and contained only $36.1 \%$ canonical biology content, indicating that the knowledge it contained was weakly classified.

The revision of the content in the NCS 2, and now the CAPS, has shown a trend back towards a more strongly classified knowledge system. The NCS 2 practically reversed the canonical/humanistic ratio of the NCS 1 by increasing the canonical content to $60.5 \%$, while the present analysis reveals that the proportion of canonical content material has been increased even further in the CAPS, to $70.1 \%$. This was also noted by Mnguni (2013) in his study on the balance of curriculum ideologies in the CAPS for Life Sciences, Grade 11. He found that a multi-curriculum ideology has been adopted in the CAPS, with scholar academic (roughly equivalent to canonical in the terminology of this study, though relating more to teaching and learning) and studentcentered (more closely aligned to humanistic, but relating more to methods of 
teaching and learning than content) ideologies dominating and the social reconstruction ideology (strongly humanistic) the least in evidence.

The assessment of the weighting of core themes in biology (Table 1) provides a means of comparing knowledge in the curriculum with that in the parent discipline, as the themes were originally derived from sources in the field of production (the writings of biological philosopher Ernst Mayr, interviews with two biology professors and an analysis of two tertiary level textbooks; see Johnson, 2009 for details). In the CAPS Animal structure and functioning is weighted the most, but has decreased from one third (33.3\%) of the material in the NCS 2 to just over one quarter $(25.3 \%)$ of the material in the CAPS. The theme Life at the molecular and cellular level has increased from 16.2\% in the NCS 2 to $23.7 \%$ in the CAPS. All other themes in the CAPS have not deviated by more than $4 \%$ above or below their levels in the NCS 2. Plant structure and functioning, at just $6.9 \%$ of the content matter, remains underrepresented. In general these results suggest that in the CAPS there has been an attempt to balance the core themes more equally than in previous curricula, especially the ICS and the NCS 1 . There had been some dramatic swings in emphasis of the core themes between the ICS and the NCS 1; this was particularly notable in the themes Evolution ( $0 \%$ to $20 \%$ ), Diversity (29.8\% to $4.4 \%)$, Ecology (8.8\% to $28.9 \%)$, and to a lesser extent Animal structure and functioning (34.9\% to $20 \%$ ).

The map of the content topics (Figure 2) reveals that the CAPS largely conforms to Schmidt, Wang and McKnight's (2005) concept of curricular coherence. The material prescribed for Grade 10 is mostly foundational; this is particularly evident in the knowledge strand Life at the molecular, cellular and tissue level where the material is hierarchical, starting with organic chemistry and continuing to cells, tissues and organs. In the knowledge strand Diversity, change and continuity the foundational principles of biodiversity and classification are laid down in Grade 10 and are followed by biodiversity and classification in microorganisms and then of plants and animals in Grade 11. Similarly, the topic history of life on earth in Grade 10 leads to the study of evolution in Grade 12. The CAPS has de-emphasized the concept of body plans that was a vital component in the NCS 2 for laying down the foundations for understanding the theory of evolution in Grade 12. In the knowledge strand Life processes in plants and animals the more abstract and hence cognitively demanding topics of photosynthesis and cellular respiration, which had appeared in Grade 10 in the NCS 2, have been moved to Grade 11, swapped with the more 'concrete' topics of support and transport 
systems in plants and animals which have moved from Grade 11 in the NCS 2 to Grade 10 in the CAPS.

Conceptual progression rather than simple repetition of topics is another component of curriculum coherence to which the CAPS appears to have complied, unlike the NCS 1 where topics were repeated from grade to grade, particularly in the knowledge areas of Environmental studies and Diversity, change and continuity (Johnson et al., 2011). One apparent exception to this is in the repetition of the topic of human impact on the environment which appears in both Grades 11 and 12, though in fact this is intended to be taught in Grade 11 but re-examined in the final Grade 12 examination. Whereas the NCS 2 taught and examined the canonical knowledge of community and population ecology in Grade 12, the CAPS examines the Grade 11 humanistic topic of human impact on the environment in Grade 12.

The predominance of solid connecting lines between the topic boxes reveals that the architects of the CAPS were concerned to make the links between and within the knowledge strands and grades explicit; this is another of Schmidt et al.'s (2005) criteria for a coherent curriculum. This is also in keeping with the nature of disciplinary biological knowledge which, according to Campbell and Reece (2005, p.ix), "is more like a web of related concepts without a fixed starting point or a prescribed path".

\section{Conclusions and implications}

Using the criteria established by the conceptual framework of this study, our study suggests that in terms of knowledge classification, the inclusion and balance of biology's core themes, and the coherence of the curriculum, the CAPS for Life Sciences does reflect the hierarchical knowledge structure of its parent discipline biology.

What are the implications of these findings? Following the logic of Bernstein and others (e.g. Maton and Muller, 2007), this should have positive consequences for South African students, inducting them successfully into the powerful knowledge of the discipline of biology. But whether a more canonical or more humanistic approach is more empowering for students remains a matter for debate. Aikenhead (2006) held that a humanistic approach is the best means to foster student self-identity, achievement and empowerment, while Mnguni's (2013) findings led him to conclude that the 
Grade 11 CAPS for Life Sciences would serve to advance the discipline, but not empower students in relation to current social challenges.

Assessing these more abstract consequences of a curriculum would be valuable, though challenging. A more direct (though arguably flawed) measure, is to consider student academic performance. In terms of matric results, for example, Table 2 below reveals an interesting trend.

Table 2: Percentage of students who passed the final matric examination with over $\mathbf{4 0 \%}$ in four consecutive South African Biology/Life Sciences curricula

\begin{tabular}{|l|c|c|c|}
\hline \multicolumn{1}{|c|}{ Curriculum } & $\begin{array}{c}\text { Year of matric } \\
\text { examination }\end{array}$ & $\begin{array}{c}\text { Percentage of sudents } \\
\text { who passed above 40\% }\end{array}$ & Source \\
\hline BCS & 2007 & 68 & DoE, 2007 \\
NCS 1 & (last year examined) & 39 & DoE, 2008 \\
Life Sciences & (first year examined) & & DBE, 2014 \\
NCS 2 & 2011 & 46.2 & DBE, 2014 \\
Life Sciences & (first year examined) & & \\
CAPS & 2014 & & \\
Life Sciences & (first year examined) & & \\
\hline
\end{tabular}

Numerous factors obviously account for student performance in matric examinations, and direct causation is not intended to be implied here.

Nevertheless, it is still interesting to note that the percentage of students who passed with over $40 \%$ was highest for the curriculum in which knowledge was the most strongly classified i.e. the ICS, and fell to just $39 \%$ in the weakly classified NCS 1 . This figure rose to $46.2 \%$ for the first year of examination of the NCS 2 and again to $48.9 \%$ for the CAPS, in which the proportion of canonical material increased, core concepts were included in reasonably balanced proportions, and curriculum coherence is in evidence. In terms of future study and career opportunities for students, good matric results are certainly empowering, and though a pass rate of only $48.9 \%$ is hardly a 
cause for celebration, the increasing pass rate for Life Sciences is encouraging.

This is not to conclude that this latest version of the Life Sciences curriculum has reached the end of its revision trajectory, however. While our study has revealed improvements on previous versions according to the criteria we selected, it was conducted at a fairly broad scale. An examination of the content in greater detail (Dempster, Johnson and Griffiths, in prep.; Umalusi, unpublished report) has revealed several problematic aspects in the section on evolution, biology's most integrating proposition and one which still proves challenging for South African teachers (Stears, Clément, James and Dempster, 2014). This section will require attention in future versions of the curriculum.

\section{References}

Aikenhead, G.S. 2006. Science education for everyday life: evidence-based practice. New York: Teachers College Press.

Barberá, O., Zanón, B. and Pérez-Plá, J.F. 1999. Biology curriculum in twentieth century Spain. Science Education, 83: pp.97-111.

Bennett, J. 2003. Teaching and learning science. London: Continuum.

Bernstein, B. 1990. The structuring of pedagogic discourse Volume IV: class, codes and control. London and New York: Routledge.

Bernstein, B. 1996. Pedagogy, symbolic control, and identity: theory, research, critique. London: Taylor \& Francis.

Bernstein, B. 1999. Vertical and horizontal discourse: an essay. British Journal of Sociology of Education, 20(2): pp.158-173.

Bertram, C. 2008. Curriculum recontextualisation: a case study of the South African high school history curriculum. Unpublished $\mathrm{PhD}$ thesis, University of KwaZulu-Natal, Pietermaritzburg. 
Bertram, C. 2009. Procedural and substantive knowledge: some implications of an outcomes-based history curriculum in South Africa. Southern African Review of Education, 15(1): pp.45-62.

Bertram, C. 2012. Bernstein's theory of the pedagogic device as a frame to study history curriculum reform in South Africa. Yesterday and Today, 7: pp.1-22. Retrieved June 02, 2015, from http://www.scielo.org.za

Campbell, N.A. and Reece, J.B. 2005. Biology ( $7^{\text {th }}$ ed.). San Francisco: Pearson Education Inc. (Benjamin Cummings).

Chisholm, L. 2000. A South African Curriculum for the Twenty First Century. Report of the Review Committee on Curriculum 2005. Pretoria: Department of Education.

Christie, F. 2007. Ongoing dialogue: functional linguistic and Bernsteinian sociological perspectives on education. In Christie, F. and Martin, J.R. (Eds), Language, knowledge and pedagogy: functional linguistic and sociological perspectives. London: Continuum, pp.3-13.

Dempster, E.R. and Hugo, W. 2006. Introducing the concept of evolution into South African schools. South African Journal of Science, 102: pp.106-112.

Dempster, E., Johnson, K. and Griffiths, M. (in preparation). Evolution in the South African school Life Sciences curriculum: an evolving story.

Department of Basic Education. 2011. Curriculum and assessment policy statement Grades 10-12 Life Sciences. Pretoria: Department of Basic Education.

Department of Basic Education. 2014. National Senior Certificate Examination 2014 Diagnostic Report. Pretoria.

Department of Education. 2003. National Curriculum Statement Grades 10-12 (General). Life Sciences. Pretoria: Government Printers.

Department of Education. 2007. A new content framework for the Subject Life Sciences as listed in the National Curriculum Statements Grades 10-12 (GENERAL). Circular 67/2007, 25 September. Johannesburg: Department of Education. 
Department of Education. 2007. Report on the 2007 Senior Certificate examination. Pretoria: Department of Education.

Department of Education. 2008. Abridged Report: 2008 National Senior Certificate examination results. December 2008. Pretoria: Department of Education.

Department of Education. 2009. Report of the Task Team for the Review of the Implementation of the National Curriculum Statement. Pretoria: Department of Education.

Dobzhansky, T. 1973. Nothing in biology makes sense except in the light of evolution. The American Biology Teacher, 35(3): pp.125-129.

Doidge, M., Dempster, E., Crowe, A. and Naidoo, K. 2008. The Life Sciences content framework: a story of curriculum change. Proceedings of the $4^{\text {th }}$ Biennial Conference of the South African Association of Science and Technology Educators, 1-4 July 2008.

Donnelly, J. 2006. The intellectual positioning of science in the curriculum, and its relationship to reform. Journal of Curriculum Studies, 38(6): pp.623-640.

Gould, S.J. 2002. The structure of evolutionary theory. Cambridge, Massachusetts: The Belknap Press of Harvard University Press.

Green, W. and Naidoo, D. 2006. Knowledge contents reflected in postapartheid South African Physical Science curriculum documents. African Journal of Research in SMT Education, 10(1): pp.71-80.

Hasan, R. 2004. The concept of semiotic mediation: perspectives from Bernstein's sociology. In Muller, J., Davies, B. and Morias, A. (Eds). Reading Bernstein, researching Bernstein. London: RoutledgeFalmer, pp.30-43.

Hoadley, U. 2005. Social class, pedagogy and the specialization of voice in four South African primary schools. Unpublished $\mathrm{PhD}$ thesis, University of Cape Town. 
Johnson, K. 2009. Biology and its recontextualisation in the school curriculum: a comparative analysis of post-apartheid South African life sciences curricula. Unpublished MEd thesis. Pietermaritzburg: University of KwaZulu-Natal.

Johnson, K., Dempster, E. and Hugo, W. 2011. Exploring the recontextualisation of biology in the South African life sciences curriculum, 1996-2009. Journal of Education, 52: pp.27-58.

KwaZulu-Natal Department of Education and Culture. (n.d.). Interim Core Syllabus and Provincialised Guide for Biology Grades 10-12 Higher Grade and Standard Grade.

Maton, K. and Muller, J. 2007. A sociology for the transmission of knowledges. In Christie, F. and Martin, J.R. (Eds), Language, knowledge and pedagogy: functional linguistic and sociological perspectives. London:

Continuum, pp.14-33.

Mayr, E. 2001. What evolution is. New York: Basic Books.

Mnguni, L. 2013. The curriculum ideology of the South African secondary school biology. South African Journal of Education, 33(2): pp.1-11.

Moore, R., Arnot, M., Beck, J. and Daniels, H. 2006. Knowledge, power and educational reform. Applying the sociology of Basil Bernstein. London: Routledge.

Muller, J. 2000. Reclaiming knowledge: social theory, curriculum and education policy. London: RoutledgeFalmer.

Muller, J. 2007. On splitting hairs: hierarchy, knowledge and the school curriculum. In Christie, F. and Martin, J.R. (Eds), Language, knowledge and pedagogy: functional linguistic and sociological perspectives. London: Continuum, pp.65-86.

Neves, I. and Morais, A. 2001. Knowledge and values in science syllabuses: a sociological study of educational reforms. British Journal of Sociology of Education, 22(4): pp.531-556. 
Nsubuga, Y. 2008. A Bernsteinian analysis of the integration of natural resource management in the curriculum of a rural disadvantaged school. Southern African Journal of Environmental Education, 25: pp.98-112.

Project 2061. 2006. Retrieved 5 September 2006 from http://www.project2061.org

Rosenthal, D.B. and Bybee, R.W. 1987. Emergence of the biology curriculum: a science of life or a science of living? In Popkewitz, T.S. (Ed.), The formation of school subjects. The struggle for creating an American institution. New York: The Falmer Press, pp.123-144.

Schiro, M.S. 2008. Curriculum theory: conflicting visions and enduring concerns. Los Angeles, CA: SagePublications.

Schmidt, W.H., Wang, H.C. and McKnight, C.C. 2005. Curriculum coherence: an examination of US mathematics and science content standards from an international perspective. Journal of Curriculum Studies, 37(5): pp.525-559.

Stears, M., Clément, P., James, A. and Dempster, E. 2014. In South Africa, teachers' conceptions of evolution vary according to their religion. Paper presented at the $15^{\text {th }}$ IOSTE Conference, Borneo, September 2014.

Umalusi. 2014. What's in the CAPS package? Natural Sciences. Pretoria.

Umalusi. 2015. A comparative analysis of the Amended Senior Certificate (ASC) and the Curriculum and Assessment Policy Statement (CAPS). Unpublished Report. 


\section{APPENDIX 1: Criteria used in categorising statements as being either canonical or humanistic}

\begin{tabular}{|c|c|c|}
\hline Category & Elaborations & Examples from the CAPS \\
\hline $\begin{array}{l}\text { Canonical } \\
\text { (scientific } \\
\text { knowledge and } \\
\text { skills) }\end{array}$ & $\begin{array}{l}\text { - scientific facts, concepts, } \\
\text { principles, hypotheses, theories } \\
\text { and laws } \\
\text { - skills, abilities, methods, } \\
\text { techniques and processes } \\
\text { specifically concerned with the } \\
\text { study of science and doing } \\
\text { scientific investigations, such } \\
\text { as observation, hypothesis } \\
\text { formation, data collection and } \\
\text { processing, laboratory } \\
\text { procedures, and the } \\
\text { communication of scientific } \\
\text { findings } \\
\text { - preparation for future studies } \\
\text { and careers in the sciences. }\end{array}$ & $\begin{array}{l}\text { Grade 10: } \\
\text { - Carbohydrates - monosaccharaides } \\
\text { (single sugars), e.g., glucose and } \\
\text { fructose (p.24) } \\
\text { - Explain and demonstrate how a } \\
\text { light microscope works (p.25) } \\
\text { Grade 11: } \\
\text { - Hormonal control of blood sugar } \\
\text { levels (p.43) } \\
\text { - Composition of inspired air vs. } \\
\text { expired air - analyse data (p.47) } \\
\text { Grade 12: } \\
\text { - DNA - location in the cell; } \\
\text { chromosomes, genes and } \\
\text { extranuclear DNA (p.54) } \\
\text { - Perform a simple process to extract } \\
\text { DNA and examine the threads } \\
\text { (p.54) }\end{array}$ \\
\hline $\begin{array}{l}\text { Humanistic } \\
\text { (generic skills; } \\
\text { applications of } \\
\text { science to } \\
\text { everyday life and } \\
\text { society; attitudes } \\
\text { and values; } \\
\text { science } \\
\text { as a human } \\
\text { enterprise) }\end{array}$ & $\begin{array}{l}\text { - generic skills such as critical } \\
\text { thinking, problem solving, } \\
\text { communication and co-operation. } \\
\text { - understanding and solving } \\
\text { problems regarding the scientific } \\
\text { or technological apects of daily } \\
\text { life; science as a means for } \\
\text { solving problems in society and } \\
\text { the environment, as well as the } \\
\text { limits of science in solving } \\
\text { problems, and the potential for } \\
\text { the applications of science and } \\
\text { technology to harm the individual } \\
\text { and the environment. } \\
\text { - attitudes and values such as } \\
\text { objectivity, respect for evidence, } \\
\text { critical thinking, openness, } \\
\text { honesty; the fostering of positive } \\
\text { attitudes towards science; } \\
\text { satisfying curiosity; promoting } \\
\text { appreciation and respect for } \\
\text { nature; ethics. } \\
\text { - the nature of science; the } \\
\text { history of science and scientific } \\
\text { discoveries }\end{array}$ & $\begin{array}{l}\text { Grade 10: } \\
\text { - The nature of science: science } \\
\text { involves contested knowledge, and } \\
\text { non-dogmatic inferences based on } \\
\text { evidence and peer review (p.10) } \\
\text { - Analyse nutritional content } \\
\text { indicated on food packaging: } \\
\text { vitamins, minerals and other } \\
\text { nutritional content (p.23) } \\
\text { Grade 11: } \\
\text { - The number of people affected by } \\
\text { diabetes in recent years (p.43) } \\
\text { - Draw up a public survey form to } \\
\text { test the public opinion about culling } \\
\text { (p.49) } \\
\text { Grade 12: } \\
\text { - Discovery of the structure of DNA } \\
\text { by Watson, Crick, Franklin and } \\
\text { Wilkins (p.54) } \\
\text { DNA fingerprinting/profiling (case } \\
\text { study only) (p.54) }\end{array}$ \\
\hline
\end{tabular}




\section{APPENDIX 2: Seven broad themes in biology with some of the topics incorporated in each (after Johnson, 2009)}

\begin{tabular}{|c|c|}
\hline Theme & Topics incorporated \\
\hline $\begin{array}{l}\text { 1. Life at the } \\
\text { molecular and } \\
\text { cellular level }\end{array}$ & $\begin{array}{l}\text { - the chemistry of life (biological compounds and nutrients) } \\
\text { - the microscope; cell structure and function } \\
\text { - diffusion and osmosis } \\
\text { - mitosis } \\
\text { - cellular respiration } \\
\text { - photosynthesis }\end{array}$ \\
\hline 2. Inheritance & $\begin{array}{l}\text { - meiosis } \\
\text { - DNA, RNA and protein synthesis } \\
\text { genetics }\end{array}$ \\
\hline 3. Evolution & $\begin{array}{l}\text { - basic principles of evolution (Lamarck; Darwin; sources of } \\
\text { variation; } \\
\text { - adaptation; speciation; natural selection) } \\
\text { - biogeography } \\
\text { - the geological time scale } \\
\text { - the fossil record } \\
\text { - extinctions } \\
\text { - human evolution }\end{array}$ \\
\hline 4. Diversity & $\begin{array}{l}\text { - concept of biodiversity } \\
\text { - classification as a system of organisation in biology } \\
\text { - viruses, bacteria, protists and fungi } \\
\text { - plant and animal diversity (examples and basic features of major } \\
\text { groups) }\end{array}$ \\
\hline $\begin{array}{l}\text { 5. Plant (angiosperm) } \\
\text { structure and } \\
\text { functioning }\end{array}$ & $\begin{array}{l}\text { - tissues and organs } \\
\text { - structural support } \\
\text { - movement of water through the plant, from uptake to transpiration } \\
\text { - translocation of manufactured food } \\
\text { - responses to the environment } \\
\text { - gaseous exchange } \\
\text { reproduction }\end{array}$ \\
\hline $\begin{array}{l}\text { 6. Animal (mammalian } \\
\text { - human) structure } \\
\text { and functioning }\end{array}$ & $\begin{array}{l}\text { - tissues } \\
\text { - structural support (skeleton, joints and muscles) } \\
\text { - transport (heart, blood and lymph) } \\
\text { - responses/ co-ordination (nervous and endocrine systems) } \\
\text { - gaseous exchange } \\
\text { - excretion } \\
\text { - reproduction } \\
\text { - immunity }\end{array}$ \\
\hline 7. Ecology & $\begin{array}{l}\text { - basic ecology (biosphere, biomes and ecosystems; biotic and } \\
\text { abiotic factors; trophic relationships; energy flow; nutrient cycling) } \\
\text { - population studies (population parameters; estimates of population } \\
\text { size; population regulation) } \\
\text { - community interactions (competition; predation; parasitism; } \\
\text { mutualism; commensalism) }\end{array}$ \\
\hline
\end{tabular}


Kathryn Johnson

School of Life Sciences

University of KwaZulu-Natal

johnson@ukzn.ac.za

Edith Dempster

Wayne Hugo

School of Education

University of KwaZulu-Natal

dempstere@ukzn.ac.za

hugow@ukzn.ac.za 
